\title{
EFFICIENCY OF BATCH MODEL BIODIGESTERS IN THE TREATMENT OF SWINE MANURE IN DEEP LITTER
}

\author{
Michelle Pellizer de Andrade \\ Federal University of Lavras (UFLA), Engineering Dept., P.O. Box 3037, ZIP Code 37,200-000, Lavras-MG, Brazil \\ Corresponding author: michelle.pellizer@gmail.com
}

Alessandro Torres Campos

Federal University of Lavras (UFLA), Engineering Dept., P.O. Box 3037, ZIP Code 37,200-000, Lavras-MG, Brazil

Rômulo Marçal Gandia

Federal University of Lavras (UFLA), Engineering Dept., P.O. Box 3037, ZIP Code 37,200-000, Lavras-MG, Brazil

Rosicler Tavares do Amaral Tonelli

Federal University of Lavras (UFLA), Engineering Dept., P.O. Box 3037, ZIP Code 37,200-000, Lavras-MG, Brazil

\section{Luiza Nazaré da Silva Freitas}

Federal University of Lavras (UFLA), Engineering Dept., P.O. Box 3037, ZIP Code 37,200-000, Lavras-MG, Brazil

\section{Jacqueline Cardoso Ferreira}

Federal University of Lavras (UFLA), Engineering Dept., P.O. Box 3037, ZIP Code 37,200-000, Lavras-MG, Brazil

\begin{abstract}
Swine production is characterized as a potentially harmful activity to the environment. Therefore, it is necessary to find alternatives that can minimize problems caused by this activity. Among the alternatives, we highlight the use of deep litter, which provides a breeding system that promotes the treatment of waste in solid form. The digester is used as an adjunctive treatment to the deep litter as this alone is not sufficient to remove all content of polluting waste. The objective of study was to evaluate the efficiency of laboratory digesters in reducing pollutant loads from swine deep litter. Deep litter composed of wood shavings and sugarcane bagasse was used. Samples were collected at the inlet and outlet of the biodigester. Six model laboratory batch digesters with a volume of 20 liters were used in treatment. For the efficiency reduction pollutants manure analysis, the following physical-chemical parameters were analyzed in the inlet and outlet: Biochemical Oxygen Demand (BOD), Chemical Oxygen Demand (COD), Total Solids (TS), total nitrogen, total phosphorus and $\mathrm{pH}$. The mean removal efficiencies of BOD, COD, TS were $53.38 ; 54.53 \%$ and $44.97 \%$, respectively. Based on the results it was found that the anaerobic treatment system was effective to reduce and stabilize the organic matter of the manure. There was an increase in total nitrogen and total phosphorus after treatment, which makes its favorable for use as a biofertilizer. There were no significant changes in $\mathrm{pH}$ indicating good tamponade of the system.
\end{abstract}

Index terms: Anaerobic biodigestion, swine facilities, alternative management, sustainability.

Received: August, 30, 2018 - Accepted: October, 24, 2018

\section{INTRODUCTION}

Swine producers are constantly seeking to increase productivity, so they adopt confined swine production systems that significantly increase the contribution of waste. The inadequate management of these wastes can cause pollution, which causes ecological changes in several Brazilian cities (Angonese et al., 2006; Carvalho, Melo and Soto, 2015). The impacts on soil and water are the main consequences of this activity (Oliveira, 2004).

In order to reduce the water demand and contamination by agricultural activities, it is necessary to use alternative technologies. One of the systems currently used is swine breeding in deep litter, which has shown satisfactory results for this type of approach (Higarashi et al., 2008).

The swine breeding system in deep litter has been an alternative adopted as a way to enable 
the management of the wastes in the solid form. The system replaces the concrete floor and consists of a bed composed of some type of absorbent material such as: shavings, rice husks, grass straw, sugarcane bagasse, among others (Gomes et al., 2014).

The use of the deep litter system by itself is not sufficient, however, for total degradation of the waste, making another form of subsequent treatment necessary for its final deposition.

One system that emerges as a positive alternative in the treatment of animal waste is the anaerobic digestion. This process is able to solve several problems, such as environmental pollution, the feasibility of economic enterprises in small and medium rural properties and the generation of renewable energy (Wenzel et al., 2014).

In this context, the biodigesters have been highlighted as a type of biological reactor that promotes the degradation of animal wastes under anaerobic conditions, bringing as biofertilizer and biogas products (Kunz and Oliveira, 2008).

The biodigester is composed, basically, of two parts: a closed chamber, where the biomass is stored and digested, and a gasometer that serves to store the biogas generated.

The adoption of the biodigester system for the treatment of manure from swine breeding presents environmental and economic advantages. Some of these advantages are: high reductions in pollutant loads; reduction of greenhouse gas emissions beyond their use as alternative fuel and nutrient-rich organic fertilizer (Konzen, 2006).

The biodigester of the batch model has gained space in the market. Because it presents a low cost and operational facility, it has proved very useful in situations where the waste is received periodically (Oliveira, 2004).

The characterization of biomass is animportant procedure to verify the operating conditions of the biodigesters and the environmental impacts related to the inadequate disposal of the waste. This verification is done through physicalchemical parameters (Fernandes et al., 2014; Silva et al., 2015).

The aim of the present study was to evaluate the efficiency of laboratory batch model biodigesters in the reduction of the pollutant load in swine deep litter made from sugarcane bagasse and wood shavings.

\section{MATERIAL AND METHODS}

The experiment were developed at the Laboratory of Rural Constructions, Ambience and Waste Treatment of the Engineering Department at Federal University of Lavras, located in the municipality of Lavras, state of Minas Gerais.

\section{Facilities characterization}

The deep litter used in the experiment was collected at the swine facilities of the Swine Sector of the Federal Institute of Education, Science and Technology Southeast of Minas Gerais - Rio Pomba Campus, located in the municipality of Rio Pomba, state of Minas Gerais. The place is located at the average altitude of $434 \mathrm{~m}$, with geographical coordinates $21^{\circ} 16^{\prime} 45^{\prime \prime}$ south latitude and $43^{\circ} 10^{\prime} 30^{\prime \prime}$ west longitude. The climate of the region, according to Köeppen classification is Cwa (hot temperate, rainy, with dry season in winter and hot summer).

The pig production facility in deep litter has the following constructive characteristics: $35.0 \mathrm{~m}$ in length, $20.0 \mathrm{~m}$ in width, $3.0 \mathrm{~m}$ of right foot and masonry partitions along the sheds. The eave has $1.0 \mathrm{~m}$ and the roof is composed of ceramic tile.

The used bay was covered with $50 \mathrm{~cm}$ of thickness with the mixture of sugarcane bagasse and shavings, being $25 \mathrm{~cm}$ for each substrate (Figure 1). The bay has a concrete floor with dimensions of $4.0 \times 3.0 \mathrm{~m}$, under the bed, and is equipped with a masonry feeder and two drinking fountains.

The same bed was used for three consecutive batches of swine in the finishing phase. However, whenever necessary, the material was revolved when the bed had excess moisture.

\section{Acquisition of samples}

In order to collect samples of the deep litter of the sugarcane bagasse and shavings mixture, the standardized methodology was used to sample contaminated areas with systematic distribution of points (Cetesb, 1999). 


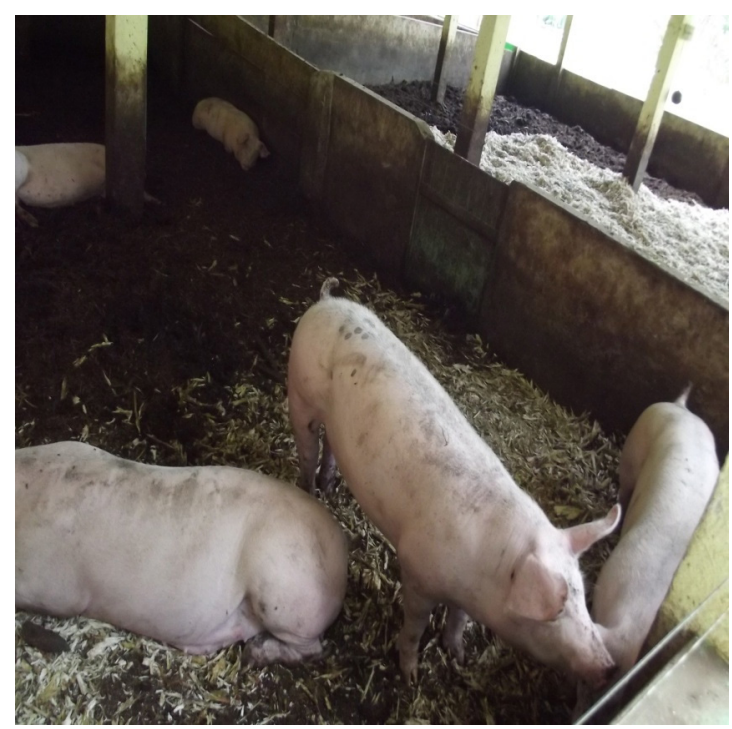

Figure 1: Overlapping bed of sugarcane bagasse and shavings.

The samples were collected at a depth of $50 \mathrm{~cm}$ at various points in the bay and homogenized to obtain a representative compost sample (Figure 2). Afterwards, they were inserted in plastic bags and taken to the laboratory, for the accomplishment of the physical-chemical analyzes, for later supply of the biodigesters.

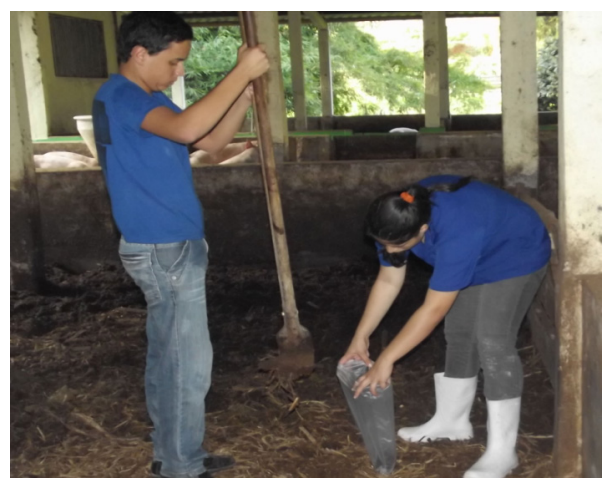

Figure 2: Collect of deep litter.

\section{Physical-chemical parameters and data analysis}

The physicochemical analyzes were performed in the Laboratory of Water Analysis of the Department of Engineering (LAADEG) of the Federal University of Lavras. The mixture was analyzed at the inlet and outlet of biodigesters, following the methodology recommended by Apha (2005).
The following parameters were analyzed: biochemical oxygen demand (BOD), chemical oxygen demand (COD), hydrogen ionic potential $(\mathrm{pH})$, total nitrogen (NTK), total phosphorus $(\mathrm{P})$ and total solids (TS).

The statistical analyzes of the affluent and effluent data were performed using statistical software Minitab 16.1.0 (Minitab, 1995). Boxplot graphs were presented, exhibiting medians, means, concentration quartiles and the removal efficiency of the analyzed parameters.

\section{Characteristics and supply of biodigesters in laboratory scale}

Six batch model laboratory biodigesters were built, consisting of high density polyethylene (HDPE), with a useful capacity of 20 L. Each one had an independent gasometer. The gasometers were made with PVC pipe (Figure 3).

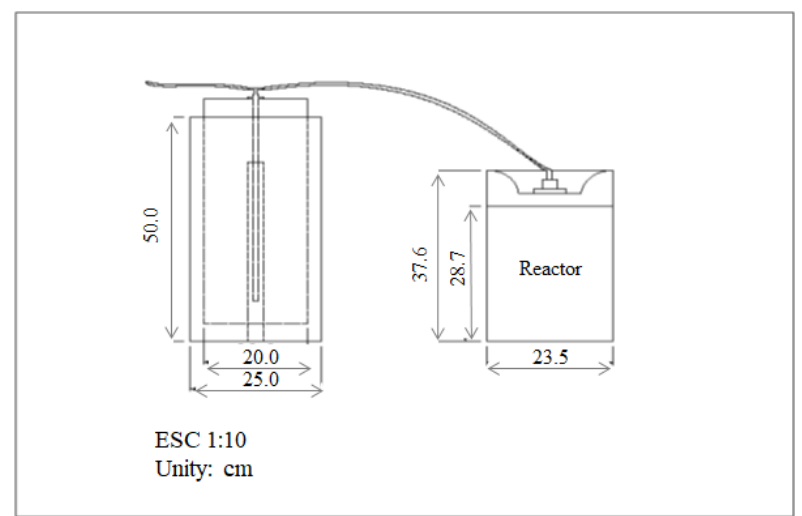

Figure 3: Dimensioning of biodigesters.

The biodigesters were filled only once and the hydraulic retention time (HRT) was 60 days.

The bed material was analyzed on total solids before it passed through the biodigesters. The bed was diluted until the total solids content was 6\%, following the methodology described by Lucas Júnior (1994). To supply the 6 biodigesters each received $4 \mathrm{~kg}$ of deep litter, $14 \mathrm{~kg}$ of water and $2 \mathrm{~kg}$ of inoculum.

The inoculum used came from the effluent of a Canadian model biodigester, which was fed with liquid manure of swine. Figure 4 illustrates the biodigesters used in the research. 


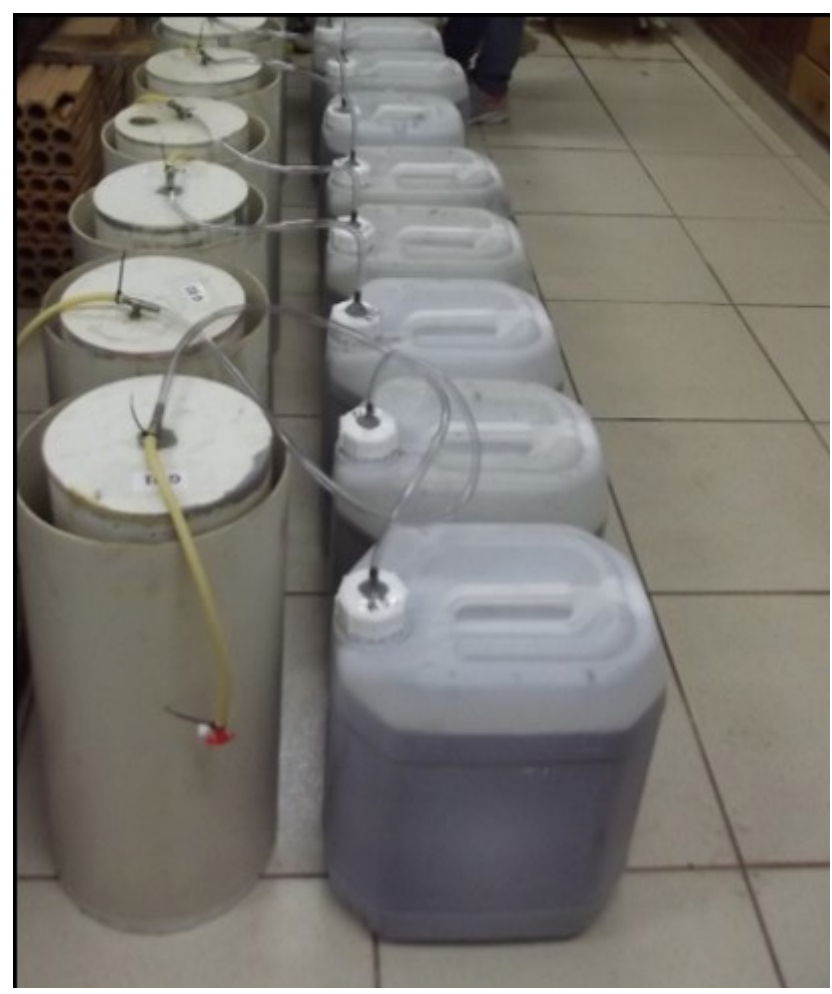

Figure 4: Laboratory bench biodigesters and their respective gasometers used in the biodigestion of the bed composed by sugarcane bagasse and shavings.

\section{RESULTS AND DISCUSSION}

Table 1 presents the mean values and total efficiency of the physicochemical parameters: biochemical oxygen demand (BOD), chemical oxygen demand (COD) and total solids (TS), related to the inlet and outlet of biodigesters.

Table 1: Average contents of the physicalchemical parameters and reductions in percentage of the variables after treatment in the biodigesters.

\begin{tabular}{cccc}
\hline Parameters & In $\left(\mathrm{mg} \mathrm{L}^{-1}\right)$ & Out $\left(\mathrm{mg} \mathrm{L}^{-1}\right)$ & Total efficiency $(\%)$ \\
\hline BOD & 10191.52 & 4751.15 & 53.38 \\
COD & 26292.21 & 11954.09 & 54.53 \\
TS & 24091.06 & 13256.86 & 44.97 \\
\hline
\end{tabular}

Biochemical Oxygen Demand (BOD), Chemical Oxygen Demand (COD), Total Solids (TS).

\section{Biochemical Oxygen Demand}

The mean concentrations of BOD at the inlet and outlet of the biodigester were 10191.52 and
$4751.15 \mathrm{mg} \mathrm{L}^{-1}$ respectively, and mean removal efficiency of $53.38 \%$. For the median, the value found for the reduction percentage was $56.18 \%$ (Figure 5).

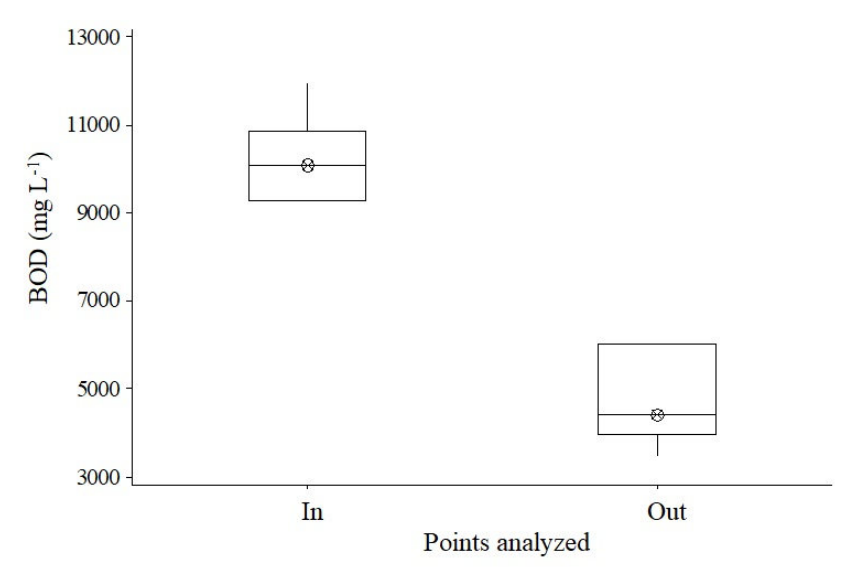

Figure 5: Median values for biochemical oxygen demand (BOD) in deep litter for swine of sugarcane bagasse + shavings at the inlet and outlet of batch model biodigesters.

The value found for BOD at the entrance to the biodigester is considered low and is at the limit of what Von Speling (2005) considers, which says that the BOD concentration for swine manure is in the range of 10000 to $50000 \mathrm{mg} \mathrm{L}^{-1}$. This fact can be explained by because the deep litter decomposes inside the facilities, being considered a pretreatment.

Fernandes et al. (2014), studying two Canadian biodigesters in series to treat swine liquid waste, found average values of $15756.31 \mathrm{mg} \mathrm{L}^{-1}$ in the tributary and $5139.6 \mathrm{mg} \mathrm{L}^{-1}$ in the effluent for BOD. The authors found a reduction of $67.38 \%$, higher efficiency than the one found in the present study, possibly due to the system being composed of two biodigesters and the waste being liquid, which accelerates the degradation of organic matter.

The BOD values obtained for the mean and median were close to each other, which indicates that the data are approximately symmetrical.

\section{Chemical oxygen demand}

In the affluent and effluent of the biodigester, the average concentrations of chemical oxygen demand (COD) were 26292.21 and $11954.09 \mathrm{mg}$ $\mathrm{L}^{-1}$, respectively, with a reduction of $54.53 \%$. 
For the median, the reduction reached $52.79 \%$ (Figure 6).

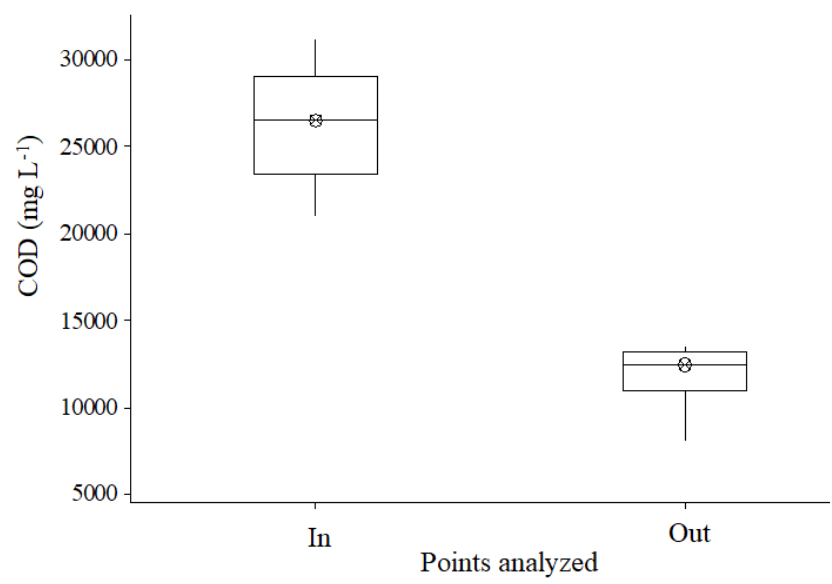

Figure 6: Median values for chemical oxygen demand (COD) in deep litter for swine of sugarcane bagasse + shavings at the inlet and outlet of batch model biodigesters.

Vivan et al. (2010) using an intermittently supplied biodigestor, with sludge from a swine waste treatment plant, obtained a reduction of $43.79 \%$, with inlet and outlet values of 41889 and $23545 \mathrm{mg} \mathrm{L}^{-1}$, respectively. Efficiency lower than found in this word. However, using a complete treatment system, composed of a biodigestor and stabilization ponds, these researchers observed an efficiency of $98 \%$, by using an association system of treatment.

Fernandes et al. (2014) evaluated the efficiency of two biodigesters in the treatment of swine effluents and obtained an efficiency of $52.61 \%$ in COD removal, a value close to that found in the present study.

Campos et al. (2006) observing the COD averages for the affluent and effluent of an UASB reactor, obtained 1744 and $379 \mathrm{mg} \mathrm{L}^{-1}$, respectively, with average removal efficiency of $78 \%$. The authors used a UASB reactor for the treatment of swine manure.

Wenzel et al. (2014), analyzing a swine waste treated with modified Canadian biodigestor waste, obtained an efficiency of $72.8 \%$ for COD.

It is noted that the COD efficiency found is inferior to some studies presented, the reason is because the waste was treated in the form of flakes, which is how the deep litter bed presents, making it difficult to degradation.

\section{Total solids}

The TS averages of affluent and effluent from the treatment of biodigesters were 24091.06 and $13256.86 \mathrm{mg} \mathrm{L}^{-1}$, respectively, with mean removal efficiency of $44.97 \%$. Regarding the median, the efficiency was $53.30 \%$ (Figure 7).

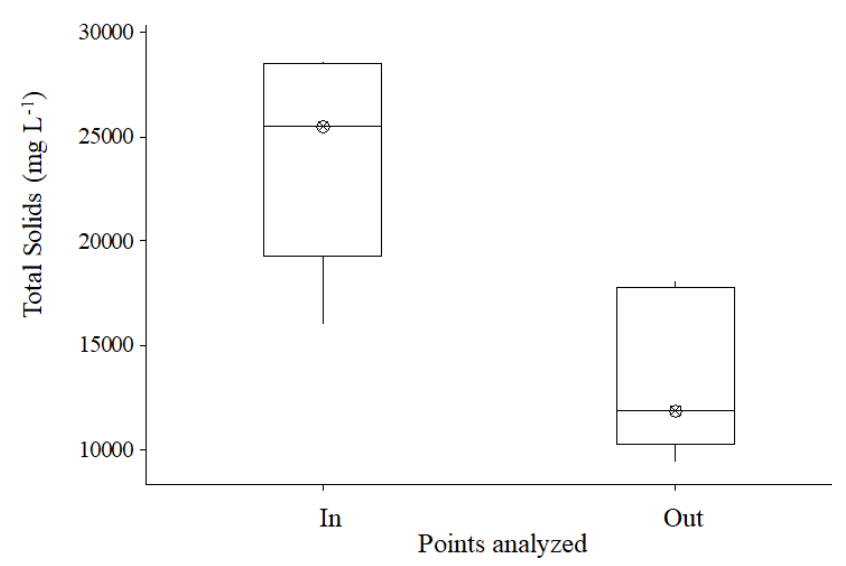

Figure 7: Median values for total solids (TS) in deep litter for swine of sugarcane bagasse + shavings at the inlet and outlet of batch model biodigesters.

Using a modified Canadian biodigester, Wenzel et al. (2014), reached an efficiency of 47.5\% for TS, a value close to that found in this study.

Evaluating an intermittent flow biodigester, Vivan et al. (2010), observed a removal efficiency of $24.16 \%$ for TS, using sludge from a swine manure treatment plant. This lower value can be justified because it is sludge, material physically different from the deep litter swine.

In the anaerobic biodigestion process, the TS are reduced to biogas due to the conversion of the organic matter. This process reduces, significantly, the pollutant load of the waste (Mondardo et al., 2016).

The results found in the literature showed a greater TS reduction. This can be attributed to the fact that they are liquid waste with more soluble nutrients and the smaller particle size, therefore, more easily degradable by the microorganisms inside the biodigesters (Orrico Junior, Orrico and Lucas Júnior, 2009).

\section{Hydrogen potential}

The mean values obtained for $\mathrm{pH}$ at the inlet (affluent) and outlet (effluent) are shown in Table 2. 
Table 2: Mean values of Hydrogen potential $(\mathrm{pH})$ in the affluent and effluent of biodigesters.

\begin{tabular}{ccc}
\hline Parameter & In & Out \\
\hline $\mathrm{pH}$ & 8.0 & 7.1 \\
\hline
\end{tabular}

The mean values of the input and output of the biodigesters did not show a significant difference, it shows that there were adequate tamponade conditions, which means the ability of the medium to neutralize acids.

With the $\mathrm{pH}$ values obtained, it was possible to verify that the biodigestor operated correctly and showed a satisfactory functioning.

Rodrigues et al. (2010) obtained values of $\mathrm{pH}$ above 7.0, showing that the UASB reactor operated stably throughout the experimental period for the treatment of swine manure.

For optimum growth of methane-producing microorganisms, the appropriate $\mathrm{pH}$ range is between 6.6 and 7.4, although stability can be achieved in the formation of methane in the range of 6.0 to 8.0. Values below or above this range should be avoided as they may completely inhibit methane-producing microorganisms (Chernicharo, 2016).

The medians found at the inlet and outlet of the biodigesters was 8.0 and 7.0, that is, practically, the same values found for the means (Figure 8).

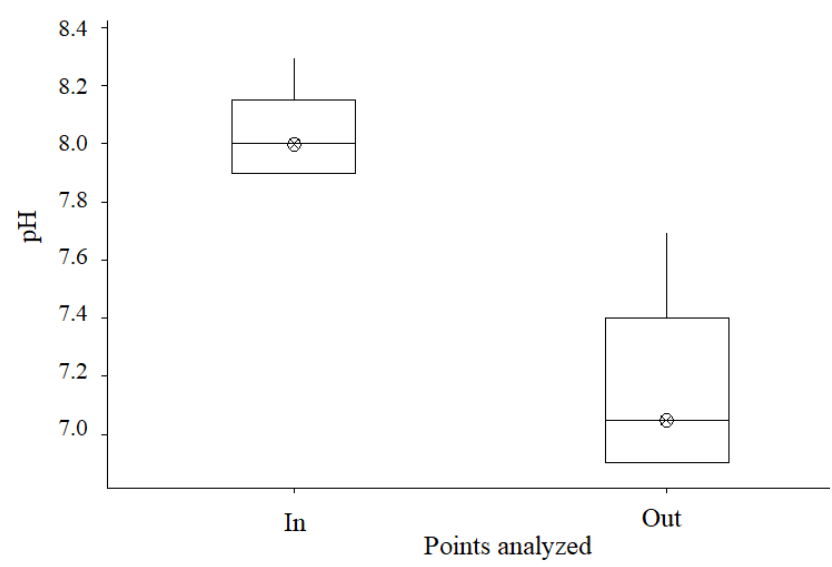

Figure 8: Median values for $\mathrm{pH}$ in deep litter bed for swine of sugarcane bagasse + shavings at the inlet and outlet of batch model biodigesters.

It was observed a reduction of the $\mathrm{pH}$ for medium and median values, indicating that the organic acids forming bacteria fractionated the substrates, increasing the amount of $\mathrm{H}+$ ions, responsible for the drop in $\mathrm{pH}$.

\section{Total nitrogen and total phosphorus}

The mean values obtained for total nitrogen and total phosphorus at the inlet (affluent) and outlet (effluent) are shown in Table 3.

Table 3: Mean values of total nitrogen and total phosphorus in the affluent and effluent of the biodigesters.

\begin{tabular}{ccc}
\hline Parameters & In $\left(\mathrm{mg} \mathrm{L}^{-1}\right)$ & Out $\left(\mathrm{mg} \mathrm{L}^{-1}\right)$ \\
\hline NTK & 696.62 & 710.64 \\
P & 43.98 & 45.12 \\
\hline
\end{tabular}

The medians for total nitrogen in the affluent and effluent were 715.3 and $720.7 \mathrm{mg} \mathrm{L}^{-1}$, respectively (Figure 9). The medians found for total phosphorus were 45.78 and $45.22 \mathrm{mg} \mathrm{L}^{-1}$, respectively for inlet and outlet (Figure 10).

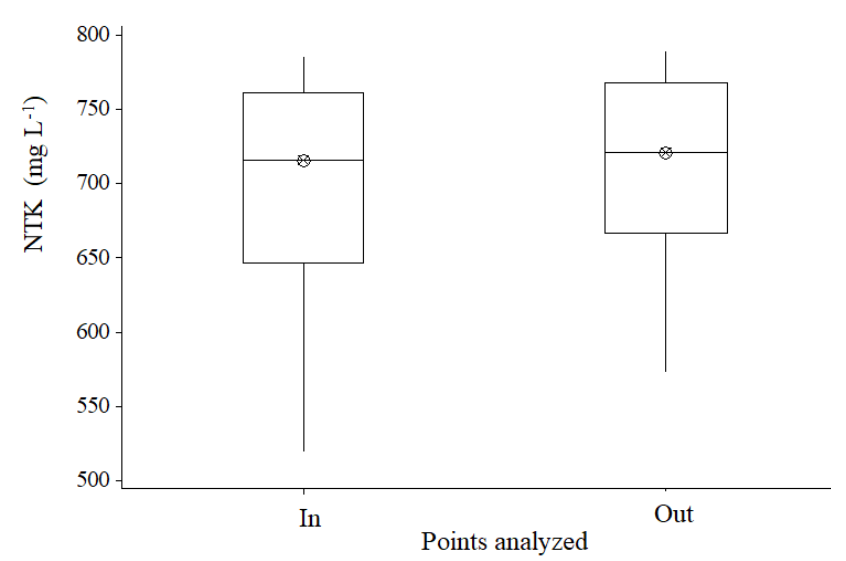

Figure 9: Median values for total nitrogen in deep litter bed for swines of sugarcane bagasse + shavings at the inlet and outlet of the batch model biodigesters.

Vivan et al. (2010), using the treatment of swine manure with intermittent supply, obtained an increase on the total nitrogen concentration from 2640 to $2832 \mathrm{mg} \mathrm{L}^{-1}$, from the outlet in relation to inlet of biodigester. For the complete treatment involving biodigestor and stabilization ponds, the author observed $2640 \mathrm{mg} \mathrm{L}^{-1}$ at the inlet and at the outlet of the last pond a value of 269 $\mathrm{mg} \mathrm{L}^{-1}$. 


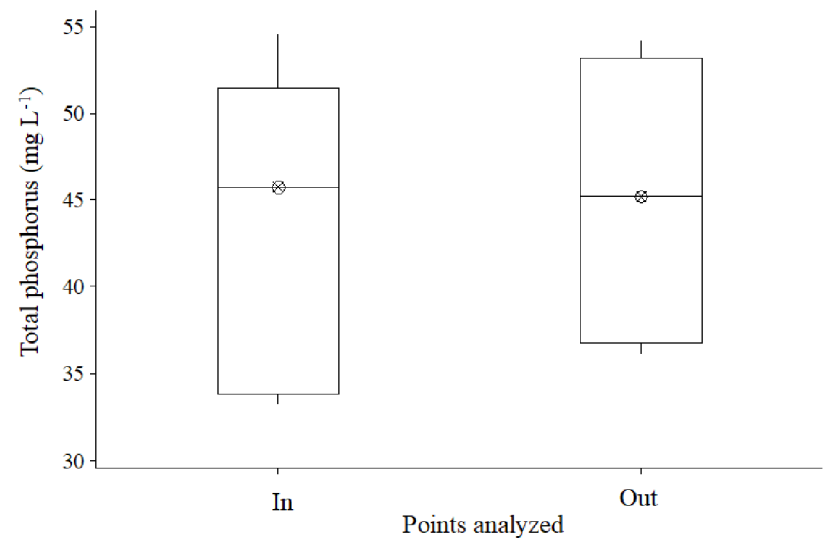

Figure 10: Median values for total phosphorus in deep litter bed for swines of sugarcane bagasse + shavings at the inlet and outlet of the batch model biodigesters.

The factor that probably led to the increase of these nutrients was due to the initial material of the deep litter presenting large particles with quite heterogeneity, not yet degraded. However, when the effluent of the biodigester was observed, the larger particles had decreased, indicating that they were degraded by the anaerobic digestion process and the nutrients contained in them could have been released, which generated this increase in total nitrogen and total phosphorus.

This increase in the amount of total nitrogen and total phosphorus enables its use as a biofertilizer since these macronutrients are essential for plants.

\section{CONCLUSIONS}

The deep litter bed of sugarcane bagasse and shavings from swine manureafter passing through the biodigesters presented a decrease of $53.38 \%$, $54.53 \%$ and $44.97 \%$ in their physical-chemical parameters in BOD, COD and TS, respectively, being efficient in reducing the pollutant load. The analysis of total nitrogen and total phosphorus indicated that the swine manure at the outlet of the biodigestor accumulated these nutrients, which makes it possible to use the effluent as fertilizer. The swine manure did not show significant $\mathrm{pH}$ variation after the biodigesters exit, this indicates that the system presented a good buffering.

\section{REFERENCES}

AMERICAN PUBLIC HEALTH ASSOCIATION. Standard methods for the examination of water and wastewater. 22st ed. NewYork: APHA, 2012, 1496p.

AMORIM, A. C.; LUCAS JÚNIOR, J. de; RESENDE, K. T. Biodigestão anaeróbia de dejetos de caprinos obtidos nas diferentes estações do ano. Engenharia Agrícola, 24(1):16-24, 2004.

ANGONESE, A. R. et al. Eficiência energética de sistema de produção de suínos com tratamento dos resíduos em biodigestor. Revista Brasileira de Engenharia Agrícola e Ambiental, 10(3): 745-750, 2006.

CAMPOS, C. M. M. et al. Desenvolvimento e operação de reator anaeróbio de manta de lodo (UASB) no tratamento dos efluentes da suinocultura em escala laboratorial. Ciência e Agrotecnologia, 30(1):140-147, 2006.

CARVALHO, B. V.; MELO, A. P.; SOTO, F. R. M. Avaliação de sistemas de gestão ambiental em granjas de suínos/Evaluation of environmental management systems on swine farms. Revista Ambiente \& Água, 10(1):164-171, 2015.

CETESB - Companhia de Tecnologia de Saneamento Ambiental. Manual de Gerenciamento de Áreas Contaminadas. Brasília, 1999.

CHERNICHARO, A. C. L. Reatores anaeróbios: princípios do tratamento biológico de águas residuárias. 2.ed. Belo horizonte: Departamento de Engenharia Sanitária e Ambiental, 2016, 379p.

FERNANDES, D. M. et al. Processo de biodigestão anaeróbia em uma granja de suínos /The anaerobic digestion process on a pig farm. Ambiência, 10(3):741754,2014

GOMES, L. P. et al. Indicadores de sustentabilidade na avaliação de granjas suinícolas. Engenharia Sanitária e Ambiental, 19(2):143-154, 2014.

HIGARASHI, M. M et al. Concentração de macronutrientes e metais pesados em maravalha de unidade de suínos em cama sobreposta. Revista Brasileira de Engenharia Agrícola e Ambiental, 12(3):311-317, 2008

KONZEN, E. A. Viabilidade ambiental e econômica de dejetos de suínos. Sete Lagoas: Embrapa Milho e Sorgo, 2006. 27p. 
KUNZ, A.; OLIVEIRA, P. A. V. Uso de biodigestores para tratamento de resíduos animais. Concórdia: EMBRAPA-CNPSA, 2008. 1p.

LUCAS JÚNIOR, J. Algumas considerações sobre o uso do estrume de suínos como substrato para três sistemas de biodigestores anaeróbios. 1994. 137 p. Tese (Livre-Docência) - Faculdade de Ciências Agrárias e Veterinárias, Universidade Estadual Paulista, Jaboticabal, 1994.

MINITAB. A beginner's guide to MINITAB statistics software. Pennsylvania: State College, 1995. 562 p.

MONDARDO, A. A. et al. Quali-Quantitative study of biogas production from bio-digestion of cutting poultry.African Journal of Agricultural Research, 11(37):3506-3513, 2016.

OLIVEIRA, P. A. V. Tecnologias para o manejo de resíduos na produção de suínos: manual de boas práticas. Concórdia: EMBRAPA-CNPSA, 2004.109p.

ORRICO JÚNIOR, M. O. P.; ORRICO, A. C. A.; LUCAS JÚNIOR, J. L. Biodigestão anaeróbia de dejetos de suínos com e sem separação da fração sólida em diferentes tempos de retenção hidráulica. Engenharia Agrícola, 29(3):474-482, 2009.

RODRIGUES, L. S. et al. Avaliação de desempenho de reator UASB no tratamento de águas residuárias de suinocultura. Revista Brasileira de Engenharia Agrícola e Ambiental, 14(1):94-100, 2010.

VIVAN, M. et al. Eficiência da interação biodigestor e lagoas de estabilização na remoção de poluentes em dejetos de suínos. Revista Brasileira de Engenharia Agrícola e Ambiental, 14(3): 320-325, 2010.

VON SPERLING, M. Introdução à qualidade das águas e ao tratamento de esgotos: princípios do tratamento biológico de águas residuárias. 3. ed. Belo Horizonte: Editora da UFMG, 2005, 452p.

WENZEL, B. M. et al. Avaliação do desempenho de um biodigestor canadense modificado no tratamento de dejetos de suínos. Engevista, 16(4):329-338, 2014. 